\title{
Evaluation of Vaccination Status Among Children with Inborn Errors of Metabolism
}

\section{Doğumsal Metabolizma Hastalığı Olan Çocukların Aşılanma Durumlarının Değerlendirilmesi}

\author{
Pınar Yılmazbaş ${ }^{1 \oplus,}$ Nafiye Emel Çakar ${ }^{2 \oplus}$ \\ ${ }^{1}$ University of Health Sciences, Okmeydani Training and Research Hospital, Pediatrics Department, Istanbul, Turkey \\ ${ }^{2}$ University of Health Sciences, Okmeydani Training and Research Hospital, Pediatric Metabolism Department, Istanbul, Turkey
}

Received: 26.10.2020 / Accepted: 05.01.2021 / Published Online: 31.03.2021

Cite as: Yılmazbaş P, Çakar NE. Evaluation of vaccination status among children with inborn errors of metabolism. Med J Bakirkoy 2021;17(1):11-7.

\begin{abstract}
Objective: Infections generate a metabolic stress in children with inborn errors of metabolism (IEM) and worsen the metabolic abnormalities. Immunization practices prevent children with IEM from vaccine preventable infections and decrease mortality and morbidity. It is recommended to vaccinate children with IEM with the same schedule applied for healthy children, but there are some precautions. The aim of this study is to investigate vaccination status and vaccine delays among children with IEM.

Methods: This cross-sectional study evaluated 99 children with IEM. Patients who were diagnosed with IEM up to 18 years of age constituted the study population. Existing comorbid conditions, and additional diseases were questioned. Immunization rates and its relationship with clinical classification, existing comorbid conditions and additional diseases were assessed. Adverse events after vaccinations were questioned. Results: Among 99 patients with IEM, 14 had vaccine delays. The incidence of vaccine delays in patients in the stable group was significantly lower than the sickest and chronic disease groups. There was statistically significant difference between comorbid conditions, additional disease(s), and presence of vaccine delay. No adverse events after vaccinations were declared.

Conclusion: Clinical characteristics of the disease, comorbid conditions and additional diseases may be the reasons of vaccine delays in patients with IEM. Questioning the vaccination status at outpatient clinics of metabolism, and opportunistic vaccination during hospitalization if possible, may prevent vaccine delays of children with IEM.
\end{abstract}

Keywords: Inborn errors of metabolism, Children, Vaccination, Metabolic diseases

öz

Amaç: Enfeksiyonlar, doğuştan metabolizma bozukluğu (DMB) olan çocuklarda metabolik bir stres oluşturarak metabolik anormallikleri kötüleştirmektedirler. Aşı uygulamaları, DMB olan çocukları aşıyla önlenebilen enfeksiyonlardan koruyarak ölüm ve morbiditeyi azaltırlar. Bu çocukların da bazı önlemler alınarak sağlıkı çocuklar ile aynı programa göre aşılanmaları önerilmektedir. Bu çalışmanın amacı, DMB olan çocukların aşılama durumu ve aşı gecikmelerini araştırmaktır.

Yöntem: Bu kesitsel çalışmada 99 DMB olan çocuk değerlendirildi. 18 yaşın altında olan ve DMB tanısı alan hastalar çalışma popülasyonunu oluşturdu. Mevcut komorbid durumlar ve eşlik eden ek hastalıklar sorgulandı. Aşılama oranları ile klinik sınıflandırma, mevcut komorbid durumlar ve ek hastalıklar arasındaki ilişkisi değerlendirildi. Aşı sonrası yan etkiler sorgulandı.

Bulgular: Doğuştan metabolizma bozukluğu olan 99 hastadan 14'ünde aşı gecikmesi mevcuttu. Stabil gruptaki hastalarda aşı gecikmesi insidansı, hastalık yükü fazla olan ve kronik hastalığı olan gruplardan anlamlı oranda düşüktü. Komorbid durum ve ek hastalık varlığı ile aşı gecikmesi arasında istatistiksel olarak anlamlı fark vardı. Hiçbir hastada aşı sonrası yan etki gelişmemişti.

Sonuç: Doğumsal metabolizma bozukluğu olan hastalarda aşı gecikmelerinin nedenleri hastalı̆ın klinik özellikleri, eşlik eden komorbid durumlar ve ek hastalıklar olabilmektedir. Bu hastaların takiplerinde aşılanma durumlarının sorgulanması ve mümkünse hastane yatışlarında aşılama yapılması aşı gecikmelerini önleyebilecektir.

Anahtar kelimeler: Doğuştan metabolizma bozukluğu, Çocuk, Aşılama, Metabolik hastalık 


\section{INTRODUCTION}

Immunization practices have beneficial effects in reducing the incidence of infectious diseases and related mortalities among children ${ }^{(1)}$. Children with inborn errors of metabolism (IEM) are more vulnerable against vaccine-preventable diseases (2). Minor infections may also decompensate the metabolic status in fragile children with IEM. Febrile episodes due to infections or inflammatory processes generate an additional metabolic stress for these patients. Poor feeding, vomiting, diarrhea caused by infections worsen the metabolic abnormalities $(2,3)$. It was seen that the initial onset of clinical manifestations of metabolic diseases may manifest with infections ${ }^{(4)}$.

Immunization decreases mortality and morbidity in children with IEM (3). Risk of severe metabolic decompensation due to vaccination is very low and the incidence of post-vaccination adverse events are not different than those seen in healthy individuals $(5,6)$. Studies have recommended that, children with IEM should be vaccinated with the same schedule used for healthy children unless there is a contraindication to components of the vaccines ${ }^{(7,8)}$.

There are some precautions when vaccinating children with IEM ${ }^{(7,8)}$. Some of the metabolic diseases are associated with neurological involvement and immunodeficiencies ${ }^{(9)}$. For patients who have neurological impairment, administration of pertussiscontaining vaccines is recommended when the neurologic condition is stabilized ${ }^{(8)}$. Correcting the metabolic defect significantly reduces the incidence of immunological abnormalities, and it is stated that it is safer to vaccinate when the metabolic condition is controlled ${ }^{(1)}$. For glutaric aciduria type 1, acute encephalopathy crises may occur due to vaccinations, especially during the first 6 years of age. So it is safer to hospitalize the patient and then vaccinate ${ }^{(10,11)}$. For fatty acid oxidation defects vaccinations may trigger metabolic decompensation which has a high risk for mortality and morbidity. It is recommended to start hydration treatment before the patients experience a crisis ${ }^{(12,13)}$.

Very few studies have evaluated vaccination status among children with IEM. The main aim of our study is to obtain data on vaccination status and vaccine delays in children with IEM. Another objective is to question the adverse events that emerge-after vaccinations.

\section{MATERIAL and METHODS}

\section{Study Population}

This cross-sectional study was conducted between November 2019-March 2020 in a pediatric metabolism outpatient clinic of a university-affiliated hospital in Istanbul, Turkey. Patients who were diagnosed with IEM up to 18 years of age constituted the study population. The patients were diagnosed based on metabolic tests and/or genetic analyses. In some patients disease-related comorbid conditions, in others additional diseases apart from the metabolic diseases were seen. Existing comorbid conditions, and additional diseases were also questioned.

\section{Classification of Patients}

Metabolic diseases have wide range of clinical characteristics. In the previous studies, they were grouped according to clinical conditions and degree of risk for metabolic decompensation ${ }^{(1,5)}$. In our study, we similarly classified the patients into three groups

Table 1: Classification of metabolic diseases according to clinical characteristics.

\begin{tabular}{|c|c|c|}
\hline $\begin{array}{l}\text { Grup 1: Sickest patients } \\
\text { Those who have a high risk of morbidity } \\
\text { and/or mortality with catabolic events }\end{array}$ & $\begin{array}{l}\text { Grup 2: Chronic patients } \\
\text { Those who have slowly progressive } \\
\text { conditions }\end{array}$ & $\begin{array}{l}\text { Grup 3: Stable patients } \\
\text { Those who are not expected to have } \\
\text { metabolic decompensation }\end{array}$ \\
\hline $\begin{array}{l}\text { Amino acid disorders } \\
\text { Organic acidemias } \\
\text { Urea cycle disorders } \\
\text { Fatty acid oxidation disorders } \\
\text { Mitochondrial disorders } \\
\text { Glycogen storage diseases (GSD) types 0, I, } \\
\text { III, VI and IX }\end{array}$ & $\begin{array}{l}\text { Lysosomal storage disorders } \\
\text { Peroxysomal disorders } \\
\text { Purine and pyrimidine disorders } \\
\text { Canavan disease } \\
\text { L-2 hydroxy glutaric aciduria }\end{array}$ & $\begin{array}{l}\text { Phenylketonuria } \\
\text { Carbohydrate metabolism disorders } \\
\text { GSD types II, IV, V, VII, and VIII } \\
\text { Biotinidase deficiency } \\
\text { Alcaptonuria }\end{array}$ \\
\hline
\end{tabular}


and added 4 more metabolic diseases in these groups (Table 1). Group 1; patients who had a high risk of morbidity and/or mortality with catabolic events, Group 2; patients who had slowly progressive conditions, Group 3; patients who were not expected to have metabolic decompensation. Unlike previous studies, Canavan disease, L-2 hydroxy glutaric aciduria were included in Group 2, and biotinidase deficiency, alcaptonuria in Group 3.

\section{Immunization Data}

Immunization data of each patient were retrieved from patients' vaccination cards or demanded from primary care providers. Patients who didn't have a vaccination card or vaccination record were excluded from the study. One hundred and seventeen children with inherited metabolic disorders were included in the study. Seven patients did not want to participate in the study. Six patients could not find any evidance of previous vaccination (vaccination card or record). 4 moved to Istanbul from another city and we could not reach their vaccination cards or records. One male patient stated that he had all routine vaccines but had an incomplete vaccination card. Subsequently, 18 patients were excluded from the study and 99 patients constituted the study population. Reasons of vaccination delays and the duration of delays were questioned. If the delay was due to an acute illness, the report of illness was evaluated. Emergency admittance, metabolic attack, hospitalization or drug administration due to postvaccination adverse effects were also questioned.

Within the scope of The Expanded Program on Immunization in Turkey, hepatitis B, BCG, diphtheriatetanus-acelluler pertusis-inactivate poliovirushaemophilus influenza type b vaccine, oral poliovirus, conjugated pneumococcal vaccine, measles-mumpsrubella (MMR), varicella, hepatitis $A$ vaccines are administered routinely. Rotavirus, meningococcal, influenza, Human papilloma virus (HPV) vaccines are also recommended but not administered free of charge by the Ministry of Health. All the patients were asked if they had these vaccines not covered by insurance.

This study was approved by the hospital ethics committee and carried out according to the Principles of Declaration of Helsinki protocol. All participants provided written informed consent forms for participation in the study.

\section{Statistical Analysis}

The data were analyzed via Number Cruncher Statistical System (NCSS) 2007 Statistical Software (Kaysville, Utah, USA) package program. While evaluating the study data Mann-Whitney $U$ test was used for descriptive statistical methods (mean, standard deviation, median, frequency, ratio), and to compare two groups of quantitative variables that did not show normal distribution. Fisher's Exact test and Fisher Freeman Halton test were used to compare qualitative data. Spearman correlation analysis was used to evaluate the relationship between quantitative variables. Statistical significance was evaluated at $p<0.05$ level.

\section{RESULTS}

Among 117 participants, 99 of them were enrolled in the study. Characteristics of patients are shown in Table 2.

Table 2: Characteristics of patients.

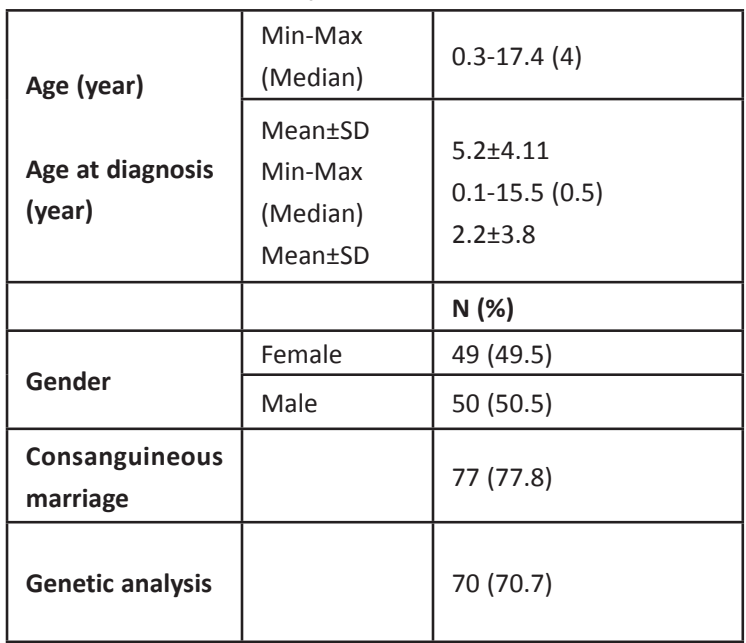

According to clinical classification, 35 (35.4\%) patients were in Group 1, 8 (8.1\%) in Group 2, and 56 (56.6\%) in Group 3, as shown in Table 3. Seventeen (17.2\%) patients had comorbid conditions related to their metabolic diseases. Comorbid conditions were; mental retardation, motor retardation, epilepsy, hydrocephalus, cerebral atrophy, immune deficiency, learning difficulties, cholestasis, heart failure, autism and anaphylaxis due to enzyme replacement treatment with elosulfase alfa. 
Table 3: Distribution of Descriptive Features.

\begin{tabular}{|c|c|c|}
\hline & & $\mathrm{N}(\%)$ \\
\hline \multirow{3}{*}{$\begin{array}{l}\text { Clinical } \\
\text { classification }\end{array}$} & $\begin{array}{l}\text { Group } 1 \\
\text { Amino acid disorders }(n=15) \text {, } \\
\text { Organic acidemias }(n=1) \text {, Urea } \\
\text { cycle disorders }(n=1) \text {, } \\
\text { Fatty acid oxidation disorders } \\
(n=13) \text {, Mitochondrial disorders } \\
(n=2) \text {, } \\
\text { Glycogen storage diseases } \\
\text { (GSD) types I-III-IX ( } n=3)\end{array}$ & $\begin{array}{c}35 \\
(35.4)\end{array}$ \\
\hline & $\begin{array}{l}\text { Group } 2 \\
\text { Lysosomal storage disorders } \\
(n=7) \text {, } \\
\text { Canavan disease }(n=1)\end{array}$ & $8(8.1)$ \\
\hline & $\begin{array}{l}\text { Group } 3 \\
\text { Phenylketonuria }(n=13) \text {, } \\
\text { Carbohydrate metabolism } \\
\text { disorders }(n=7) \text {, } \\
\text { GSD type V }(n=1) \text {, Biotinidase } \\
\text { deficiency }(n=32) \text {, } \\
\text { Alcaptonuria }(n=3)\end{array}$ & $\begin{array}{c}56 \\
(56.6)\end{array}$ \\
\hline $\begin{array}{l}\text { Comorbid } \\
\text { condition }\end{array}$ & & $\begin{array}{c}17 \\
(17.2)\end{array}$ \\
\hline $\begin{array}{l}\text { Additional } \\
\text { disease }\end{array}$ & & $7(7.1)$ \\
\hline $\begin{array}{l}\text { Vaccine } \\
\text { administered } \\
\text { apart from } \\
\text { routine } \\
\text { immunization } \\
\text { program }\end{array}$ & & $7(7.1)$ \\
\hline Vaccine delay & & $\begin{array}{c}14 \\
(14.1)\end{array}$ \\
\hline \multirow[t]{2}{*}{$\begin{array}{l}\text { Vaccine delay } \\
\text { dose } \\
\text { (number of } \\
\text { patients=14) }\end{array}$} & Min-Max (Median) & $1-17(4)$ \\
\hline & Meant $\pm S D$ & $5.7 \pm 5.0$ \\
\hline \multirow{2}{*}{$\begin{array}{l}\text { Vaccine delay } \\
\text { time (month) }\end{array}$} & Min-Max (Median) & $1-24(2)$ \\
\hline & Mean $\pm S D$ & $5.7 \pm 8.2$ \\
\hline
\end{tabular}

Seven patients (7.1\%) had additional diseases apart from metabolic disease. Additional diseases were epilepsy, Down syndrome, congenital heart defect and mucopolysaccharidosis which necessitated bone marrow transplantation for its treatment. Fourteen patients (14.1\%) had vaccine delay, and 1-17 doses were delayed for 1-24 months. Only seven patients $(7.1 \%)$ had additional unpaid vaccines (rotavirus, meningococcus, influenza) (Table 3 ).

According to the clinical classification, there was statistically significant intergroup difference between the rates of vaccine delays $(p=0.001 ; p<0.01)$. The incidence of vaccine delay in patients in Group 3 (stable patients) was significantly lower than that in Groups 1 and 2. As shown in Table 4, there was no statistically significant intergroup difference in the number of delayed doses of vaccines ( $p>0.05)$.

The incidence of vaccine delay in patients with comorbid diseases and additional diseases were found to be significantly higher than those without ( $p=0.001 ; p<0.01$ and $p=0.007 ; p<0.01$, respectively). According to the presence of comorbid diseases and additional diseases, any statistically significant intergroup difference was not found as for the delayed doses of vaccines ( $p>0.05$ ) (Table 5).

Reasons for vaccine delays of 14 patients are given in Table 6.

There was no statistically significant difference between the distribution of ages at diagnosis and presence of vaccine delay $(p>0.05)$. There was no statistically significant relationship between ages at diagnosis and delayed doses of vaccines ( $p>0.05$ ).

None of the participants declared any adverse event, metabolic attack, emergency admittance or hospitalization after vaccinations.

Table 4: Comparisons by Risk Classification.

\begin{tabular}{|c|c|c|c|c|c|}
\hline & & \multicolumn{4}{|c|}{ Risk Classification } \\
\hline & & Group 1 & Group 2 & Group 3 & $p$ \\
\hline Vaccine delay & & $8(22.9)$ & $4(50.0)$ & $2(3.6)$ & ${ }^{a} 0.001 *$ \\
\hline \multirow{2}{*}{-Vaccine delay dose } & $\begin{array}{l}\text { Min-Max } \\
\text { (Median) }\end{array}$ & $1-17(4)$ & $2-7(4)$ & $3-5(4)$ & ${ }^{b} 0.932$ \\
\hline & Mean $\pm S D$ & $6.88 \pm 6.40$ & $4.25 \pm 2.22$ & $4.00 \pm 1.41$ & \\
\hline
\end{tabular}

${ }^{a}$ Fisher Freeman Halton Test ${ }^{\mathrm{b}}$ Mann Whitney $U$ Test $* p<0.01$

- Since the number of people in the risk Group 3 is insufficient, it is not included in the comparison. 
Table 5: Comparisons According to the Presence of Comorbid and Additional Diseases.

\begin{tabular}{|c|c|c|c|c|}
\hline & & \multicolumn{3}{|c|}{ Comorbid Disease } \\
\hline & & No & Yes & $p$ \\
\hline Vaccine delay & & $6(7.3)$ & $8(47.1)$ & ${ }^{c} 0.001 *$ \\
\hline \multirow[t]{2}{*}{ Vaccine delay dose } & $\begin{array}{l}\text { Min-MaX } \\
\text { (Median) }\end{array}$ & $1-17(8)$ & $2-7(4)$ & ${ }^{b} 0.745$ \\
\hline & Mean $\pm S D$ & $8.00 \pm 7.13$ & $4.00 \pm 1.69$ & \\
\hline & & \multicolumn{3}{|c|}{ Additional disease } \\
\hline & & No & Yes & $p$ \\
\hline Vaccine delay & & $10(10.9)$ & $4(57.1)$ & ${ }^{c} 0.007^{*}$ \\
\hline \multirow[t]{2}{*}{ Vaccine delay dose } & $\begin{array}{l}\text { Min-Max } \\
\text { (Median) }\end{array}$ & $1-13(3.5)$ & 3-17 (9) & ${ }^{b} 0.102$ \\
\hline & Mean $\pm S D$ & $4.20 \pm 3.62$ & $9.50 \pm 6.61$ & \\
\hline
\end{tabular}

Table 6: Reasons for vaccine delays of 14 patients.

\begin{tabular}{|c|c|c|}
\hline Diagnosis & $\mathbf{N}$ & Reasons for vaccine delays \\
\hline Mucopolysaccharidosis type 4A (Morquio syndrome) & 1 & $\begin{array}{l}\text { After anaphylaxis due to elosulfase alfa, vaccinations were } \\
\text { delayed because there were common ingredients in both the } \\
\text { vaccines and the enzyme }\end{array}$ \\
\hline $\begin{array}{l}\text { Glutaric aciduria type } 1 \\
\text { Fatty acid oxidation disorders }\end{array}$ & $\begin{array}{l}1 \\
3\end{array}$ & $\begin{array}{l}\text { Vaccinations were delayed due to hospitalization requirement for } \\
\text { vaccinations }\end{array}$ \\
\hline $\begin{array}{l}\text { Mitochondrial disease + Mental retardation } \\
\text { Mucopolysaccharidosis type } 2+\text { Mental retardation }\end{array}$ & $\begin{array}{l}1 \\
1\end{array}$ & $\begin{array}{l}\text { School age vaccinations were delayed because the participants } \\
\text { did not attend school }\end{array}$ \\
\hline Glutaric aciduria type $1+$ hydrocephalus & 1 & $\begin{array}{l}\text { Due to shunt operation, Vaccinations were delayed because the } \\
\text { participant underwent a shunt operation }\end{array}$ \\
\hline $\begin{array}{l}\text { Fatty acid oxidation disorder + epilepsy } \\
\text { Pump + Heart Failure }\end{array}$ & $\begin{array}{l}1 \\
1\end{array}$ & $\begin{array}{l}\text { Due to hospitalization in the intensive care unit for intractable } \\
\text { epilepsy and heart failure, vaccinations were delayed }\end{array}$ \\
\hline Biotinidase deficiency + Transposition of the great arteries & 1 & Due to cardiac surgery, vaccinations were delayed \\
\hline $\begin{array}{l}\text { Urea cycle disorder } \\
\text { Niemann-Pick disease }\end{array}$ & $\begin{array}{l}1 \\
1\end{array}$ & $\begin{array}{l}\text { Because of hospitalization due to indicated diseases, vaccinations } \\
\text { were delayed }\end{array}$ \\
\hline Mucopolysaccharidosis type 1 & 1 & Due to bone marrow transplantation, vaccinations were delayed \\
\hline
\end{tabular}

\section{DISCUSSION}

Our study revealed vaccination delays and the reasons of delays among children with IEM. The rates of vaccination delays in patients with stable clinical conditions were significantly lower relative to patients with heavy disease burden and the sickest groups. Also the incidence of vaccine delays of patients who had comorbid and additional disease were found to be significantly higher than those without.

There are only few studies evaluating the immunization status of children with IEM. Compatible with our study, Cerutti et al. demonstrated suboptimal and delayed vaccination rates among these patients ${ }^{(14)}$. In that study, it was stated that low vaccination rates may be related to the negative attitude of families towards vaccination. Klein et al. evaluated 77 patients with IEM , and immunization rates of patients were found to be similar to those of healthy children, only the chronic group were less likely to receive all vaccines ${ }^{(5)}$. It is very important that patients with IEM are fully immunized and vaccinations are not delayed. Patients with IEM can easily become decompensated with vaccinepreventable diseases (VPD) and hospitalization rates due to VPD are found to be much higher than reported for healthy children ${ }^{(2,15)}$. 
When we evaluated vaccination delays according to the clinical classifications in our study; it was seen that the vaccination was delayed mostly in the clinically unstable group. In Klein et al's study the chronic patients were less likely to have received all recommended vaccines, in Cerutti et al's study the sickest and chronic group had significantly lower vaccination coverages for some of the vaccines ${ }^{(5,14)}$. However, the patients in the unstable group will suffer more from infectious diseases and mostly need immunization. In the follow-up of these patients in metabolic outpatient clinics, immunization status of the patients'must be checked in terms of incomplete and delayed vaccinations

One of the results of our study is that the incidence of vaccine delay was higher in patients who had comorbid and additional diseases. In the previous studies, immunization rates of patients with IEM were evaluated, but these circumstances were not questioned ${ }^{(5,14)}$. Investigation for vaccination delay of these patients with concomitant conditions showed that recurrent and long-standing hospitalization has a major role in vaccine delays. In fact, if there is no contraindication, inpatients can be vaccinated when they are stable. This is called opportunistic immunization, and it was seen that inpatient vaccination for patients with chronic disease can result in improvements in vaccination coverage ${ }^{(16,17)}$. Since opportunistic inpatient immunization is not a routine practice, first of all awareness should be raised in this regard.

The relationship between the age at diagnosis and delay in vaccination was not evaluated in the previous studies. In our study, we questioned the relationship between the age at diagnosis and delay in vaccination, but we could not find a significant relationship between them. We concluded that early diagnosis of the metabolic disease might not cause any delay in vaccination.

Previous studies stated that it is safe to vaccinate the patients with IEM ${ }^{(5,6,14)}$. Adverse events of immunization were reported in a very small number of people which may occur in children with unstable metabolic conditions ${ }^{(1,13)}$. There were only two case series describing metabolic decompensation after vaccinations. One study reported 7 patients with metabolic decompansation after vaccination, and 4 of these cases were not diagnosed as having inherited metabolic diseases before ${ }^{(18)}$. Another study identified two twins as having type 1 glutaric aciduria, and encephalopathy after poliovirus vaccination ${ }^{(10)}$. In our study, none of our patients reported adverse events, metabolic attack, hospitalization or emergency admittance after vaccination. Our findings have shown that vaccination is safe for such a heterogeneous group with IEM.

As a limitation of our study, we could not reach the written hospital records of adverse events occurred after vaccinations. Istanbul is a city where 16 million people live, and our patients reside in different districts. In case of emergencies they might be usually admitted to the nearest hospital. There is no common information network between hospitals, and each hospital can reach only its own records. For this reason, we relied on the statements of parents for post-immunization adverse events.

\section{CONCLUSION}

Clinical characteristics of the disease, comorbid conditions and additional diseases may be the reasons of vaccine delays in patients with IEM. In the follow-up of these patients in the metabolism outpatient clinics, questioning the vaccination status of the patients may prevent vaccine delays. In addition, at the time of vaccination of patients, administration of opportunistic vaccination can prevent delay in immunisation.

Ethics Committee Approval: Approval was obtained from the Clinical Research Ethics Committee of Okmeydanı Training and Research Hospital with protocol number: 48670771-514.10.

Funding: None

Conflict of interest: None

Informed Constent: All patients and/or legal guardians included in the study provided their written informed consent.

\section{REFERENCES}

1. Menni F, Chiarelli G, Sabatini C, Principi N, Esposito S. Vaccination in children with inborn errors of metabolism. Vaccine. 2012;30(50):7161-4. doi: 10.1016/j.vaccine.2012.10.012.

2. Varghese M, Cafferkey M, O'Regan M, Monavari AA, Treacy 
EP. Should children with inherited metabolic disorders receive varicella vaccination? Arch Dis Child. 2011;96(1):99-100. doi: 10.1136/adc.2008.147934.

3. Brady MT. Immunisation recommendations for children with metabolic disorders: more data would help. Pediatrics. 2006;118(2);810-3.

doi: $10.1542 /$ peds.2006-0846

4. Martinez-Lage JF, Casas C, Fernandez MA, Puche A, Rodriguez Costa T, Poza M. Macrocephaly, dystonia, and bilateral temporal arachnoid cysts: glutaric aciduria type 1. Childs Nerv Syst. 1994;10:198-203. doi: 10.1007/BF00301092.

5. Klein NP, Aukes L, Lee J, Fireman B, Shapira SK. Slade B, et al. Evaluation of immunization rates and safety among children with inbornerrors of metabolism. Pediatrics. 2011;127:e1139-46. doi: 10.1542/peds.2010-3706.

6. Morgan TM, Schlegel C, Erwards KM, Welch-Burke T, Zhu Y, Sparks $\mathrm{R}$, et al. Vaccines are not associated with metabolic events in children with urea cycle disorders. Pediatrics. 2011;127:e1147-53

doi: $10.1542 /$ peds.2010-1628.

7. Kingsley JD, Varman M, Chatterjee A, et al. Immunisations for patients with metabolic disorders. Pediatrics. 2006;118:e460-70. doi: 10.1542/peds.2005-1257.

8. American Academy of Pediatrics. Children with chronic disease. In: Red book: 2009 report of the committee on infectious diseases. Elk Grove Village, IL: American Academy of Pediatrics; 2009. p. 86-7.

9. Ming JE, Stiehm ER, Graham Jr JM. Syndromic immunodeficiencies: genetic syndromes associated with immune abnormalities. Crit Rev Clin Lab Sci. 2003;40:587-642. doi: 10.1080/714037692.

10. Alkan A, Baysal T, Yakinci C, Sigirci A, Kutlu R. Glutaric aciduria type 1 diagnosed after polio virüs immunisation: magnetic resonance findings. Pediatr Neurol. 2002;26:405-7. doi: 10.1016/S0887-8994(01)00411-8.

11. Kölker S, Christensen E, Leonard JV, et al. Diagnosis and management of glutaric aciduria type I - revised recommendations. J Inherit Metab Dis. 2011;34(3):677-94. doi: 10.1007/s10545-
011-9289-5.

12. Denise LM Goh. Fatty acid oxidation defects. Ann Acad Med Singapore. 2008;37(Suppl 3):74-6. Available from: https:// www.annals.edu.sg/pdf/37VolNo12SupplDec2008/ V37N12(Suppl)p74.pdf

13. Wilson K, Potter B, Manuel D, Keelan J, Chakraborty P. Revisiting the possibility of serious adverse events from the whole cell pertussis vaccine: were metabolically vulnerable children at risk? Med Hypotheses. 2010;74:150-4. doi: 10.1016/j.mehy.2009.07.014.

14. Cerutti M, Lonlay PD, Menni F, Parini R, Principi N, Esposito S. Vaccination coverage of patients with inborn errors of metabolism and the attitudes of their parents towards vaccines. Vaccine. 2015;33:6520-4. doi: 10.1016/j.vaccine.2015.10.073.

15. Smith A, Mannion M, O’Reilly P, Crushell E, Hughes J, Knerr I, et al. Rotavirus gastroenteritis is associated with Increased morbidity and mortality in children with Inherited metabolic disorders. Ir Med J. 2017;110(4):546. PMID: 28665085.

16. Plumptre I, Tolppa T, Blair M. Parent and staff attitudes towards in-hospital opportunistic vaccination. Public Health. 2020;182:39-44. doi: 10.1016/j.puhe.2020.01.006.

17. Elia S, Perrett K, Newall F. Providing opportunistic immunisation for at-risk inpatients in a tertiary paediatric hospital. J Spec Pediatr Nurs. 2017;22(1): e12167. doi: $10.1111 /$ jspn.12167.

18. Yang Y, Sujan S, Sun F, et al. Acute metabolic crisis induced by vaccination in seven Chinese patients. Pediatr Neurol. 2006;35(2):114-8. doi: 10.1016/j.pediatrneurol.2005.12.004. 